\title{
DEVELOPING THE MOTIVATION OF DEAF AND HARD OF HEARING STUDENTS TO LEARN AND ACADEMIC ACHIEVEMENT
}

\section{Professional paper}

\section{Esad H. Mahmutović ${ }^{1}$}

\section{Meliha Povlakić Hadžiefendić}

Center for Education and Rehabilitation of Deaf and Hard of Hearing Students, Tuzla, Bosnia and Herzegovina Center for Hearing and Speech Rehabilitation, Sarajevo, Bosnia and Herzegovina

Received: 05/05/2020

Accepted: 08/12/2020

\begin{abstract}
If a student's goal is academic achievement and he/she makes an effort to achieve it, he/she will become involved in classroom activities because they are a means for him/her to achieve that goal. Motivation, as an influence that brings about, directs and sustains an activity, is very important for learning. The aim of this paper is to point out the relationship between motivation to learn and academic achievement of deaf and hard of hearing students and to emphasise the importance of appropriate involvement of parents and teachers in the teaching process and the development of motivation in these students. Variables that correlate with academic achievement are presented. Views of the author are stated, which are based on research results and practice, according to which it appears that deaf and hard of hearing students usually have poorer academic achievement than their hearing peers, as well as a lower level of motivation to learn. It can be concluded that the development of interest and motivation to learn is not paid sufficient attention by both deaf and hard of hearing students themselves and their environment (parents and teachers). Where parents and teachers have high expectations of students and take into account all their personal characteristics and other factors, and where parents and teachers are appropriately involved in the teaching process, deaf and hard of hearing students show high levels of interest and motivation to learn and attain better academic achievement.
\end{abstract}

Keywords: deaf, hard of hearing, motivation, learn, academic achievement

\footnotetext{
${ }^{1}$ Correspodence to:

Esad H. Mahmutović, Center for Education and Rehabilitation of Deaf and Hard of Hearing Students, Tuzla, Bosnia and Herzegovina

Ive Andrića, 4, Tuzla Bosnia and Herzegovina

Phone: +38761290780

E-mail: esad25@yahoo.com
} 


\section{INTRODUCTION}

Becoming involved in an activity implies the existence of a reason that had led to the involvement. Persisting in this activity leads to the conclusion that there is also a certain goal which the person strives to attain by engaging in the activity. Factors that bring about an activity, sustain it and direct it towards a goal can be explained by motives. „Motives are hypothetical constructs used to explain why people are doing what they are doing. Motives are distin-guished from related constructs such as goals (the immediate objectives of particular sequences of behavior) and strategies (the methods used to achieve goals and thus to satisfy motives)“(Brophy, 2004, p. 3).

Behaviour (activity) caused by a certain motive can be attributed to motivation. Motivation encourages activity and gives it direction, intensity and duration. To be motivated means to be encouraged to do something. Motivation is a "multifaceted set of goals and beliefs that guide behavior" (Guthrie \& Wigfield, 1999, p. 199). Motivation is a theoretical construct used to explain the initiation, direction, intensity, persistence, and quality of behavior, especially goal-directed be-havior (Maehr \& Meyer, 1997; see Brophy, 2004). „Most contemporary theories of motivation assume that people initiate and persist at behaviors to the extent that they believe the behaviors will lead to desired outcomes or goals" (Deci \& Ryan, 2000, p. 227). By such motivation people are stimulated to successfully complete an assignment, achieving a goal or a degree of qualification in their professions (Mohamadi, 2006; see Amrai, Motlagh, Zalani, \& Parhon, 2011).

Motivation, as an influence that brings about, directs and sustains a desired behaviour, is very important for learning. Understandings motives and motivation of students can provide guidelines for encouraging and developing commitment to learning in order to attain better academic achievement. The importance of motivation for learning and academic achievement and for successful mastering of certain programmes that enable one to complete his/her education and to gain an academic title is reflected in the development of a positive attitude towards school and school obligations. If a student's goal is academic achievement and he/she makes an effort towards achieving this goal, he/she will become involved in classroom activities because they are a means for him/her to achieve that goal. This will ultimately be verified by grades, certificates, diplomas and the like. Lack of interest in work and school obligations is an indication that the student is not motivated or that he/ she does not understand the goal of learning.

„Multiple reasons might drive study behavior, such as a spontaneous interest in the learning material, a desire to prove oneself by getting high grades, external expectations, or future professional goals. Nevertheless, some motives might be more dominant for some students, whereas different motives might be of greater importance to others" (Vansteenkiste, Sierens, Soenens, Luyckx, \& Lens, 2009, p. 671). When it comes to deaf and hard of hearing students, they approach classroom obligations and learning with varying interest. They display different forms of behaviour and are persistent to a greater or lesser extent in performing their school obligations. These children set different goals when it comes to their academic achievement. These differences in involvement and engagement indicate the existence of different motives that drive them to action as well as different forms of motivation that sustain their action.

\section{ACADEMIC ACHIEVEMENT OF DEAF AND HARD OF HEARING STUDENTS}

„Academic achievement is one of the most important indicators of learning and understanding in all educational systems. Identifying factors affecting students' performance in this course and determining the size of these effects can be critically important in helping students improve their academic achievement" (Rahmani, 2011, p. 803). 
Deaf children possess the same intellectual potential as hearing children, they are capable of high academic achievement even when they do not have full command of all aspects of English (Miller, 2004b; see Moores $\&$ Martin, 2006). „The range of intelligence levels of students with deafness does not differ from the range in their hearing counterparts. Academic performance must not be equated with intelligence. Most children who are deaf have normal intellectual capacity and it has been repeatedly demonstrated that their scores on non-verbal intelligence tests are approximately the same as those of the general population“ (Ogundiran \& Olaosun, 2013, p. 42). „In order to fully understand the characteristics of deaf learners, including both strengths and weaknesses, it is necessary to understand the interactions of cognitive, social, and linguistic factors in the environment. Without that information, we cannot provide fair assessments of deaf students and thus we cannot educate them appropriately" (Marschark, 2001, p. 1). In fact, Marschark (2003; see Moores \& Martin, 2006), reports that research involving cognition and memory among deaf and hearing individuals consistently shows both similarities and differences in their performance. Marschark stresses that a difference does not imply a deficiency; in some tasks deaf subjects have an advantage. By further investigating and understanding relationships between cognition and deafness, we can improve educational instruction of deaf learners.

Despite the efforts of educators and parents, the academic performance of deaf children frequently lags behind that of hearing peers (Allen, 1986; Lang, 2003; Marschark, Lang, \& Albertini, 2002; Traxler, 2000; see Marschark, Convertino, \& Larock, 2006).

Stinson and Kluwin (2003; see Richardson, Marschark, Sarchet, \& Sapere, 2010) reviewed the literature with regard to academic placement for $\mathrm{DHH}$ students and concluded that the largest contribution to academic achievement came from differences in student and family characteristics (e.g., age of hearing loss onset, prior academic achievement, and parental hearing status). Apart from the obvious effects of the degree, type and quality of instruction, five variables appear to be closely correlated with the academic achievement of students with hearing impairment (Moores, 1985, Paul \& Quigley, 1990; see Ogundiran i Olaosun, (2013): 1. The severity of hearing impairment - The greater the hearing loss, the more likely the child will experience difficulty in learning language and academic skills. 2 . The age of onset of hearing loss - A child who loses his hearing before acquiring speech and language (usually before age 2 ) is at a much greater disadvantage than a child with a post lingual hearing impairment. 3. Intelligence test scores - As with children with normal hearing, higher scores on standardized tests of intelligence are correlated with greater amounts of academic success.

4. Socio-economic status of the family - A child with hearing impairment whose parents are affluent and college educated is more likely to achieve academic success than a child with hearing impairment from a low-income and less educated family. 5. The hearing status of the parents - A child with deafness from parents with deafness is considered to have better chances for academic success than a deaf child born by hearing parents, particularly if the parents are highly educated.

Degree of hearing loss does not appear to be a direct predictor of academic achievement (Allen, 1986; Powers, 2006; Tymms, Brien, Merrell, Collins, \& Jones, 2003; see Richardson et al., 2010). Nevertheless, it does affect access to communication within the classroom and has more subtle long-term effects insofar as cognitive skills, world knowledge, and fluency in language are acquired through an incremental and interactive process extending over many years. „It is assumed that due to the lack of auditory modality there is certain psychological restructuring in relation to the communication models, which in turns affects the development of cognitive functions, due to which deaf people differ significantly from hearing people in terms of psychological characteristics" (Hasanbegović \& Sinanović, 2008). Untreated hearing loss in a child has a significant impact on their auditory brain development that results in serious consequences for 
speech, language, literacy, academic achievements, and social/emotional development for the childrens life term. These chronic disabilities also impact significantly on the family and community (Olusanya, Ruben, \& Parving 2006; see Dornan, 2010).

Deficits in vocabulary, syntax and the ability to use abstract language, all of which have been documented for a large portion of deaf and hard-of-hearing children, directly impede acquisition of literacy (reading, writing) skills and thus limit academic experiences (Marschark et al, 2002; see Marschark \& Spencer, 2009). “The results of cognitive function research indicate poorer results among deaf respondents compared to the hearing ones, which is a consequence of the insufficiently developed semantic function of speech" (Hasanbegović, 2008). While the development of speech, as a learning tool, can frequently be an obstacle to learning among deaf and hard of hearing children, in order for the education process to feature optimal planning, preparation and implementation, it is important to take into account all of the children' relevant personal characteristics and all environmental factors. Stinson and Walter (1997) argued that, beyond communication, DHH students' academic success is strongly influenced by less tangible variables, such as self-efficacy, study habits, program satisfaction, and enrollment in academically rigorous courses (Powers, 2006; see Richardson et al., 2010).

Since academic achievement is the result of implementation of the rehabilitation-educational process, the question arises as to whether appropriate methods and techniques of work are applied during this process, or in other words, whether the cause of poor academic achievement of deaf and hard of hearing students may be attributed to the approach of persons who directly work with this population, or the cause is in the students themselves? „It is recommended that teachers and the professionals who work with individuals with deafness should be trained to have a deep understanding of the cultural, linguistic, sociological, psychological, educational and prosthetic aspects of deafness and continually update these skills so as to be able to offer more effective interventions" (Ogundiran \& Olaosun, 2013, p. 46).
Schick, Williams, and Kupermintz (2006; see ElZraigat, 2013) maintain that among educational needs of deaf and hard-of-hearing students are learning environment, educational interpreters, communication, using visual approach, and applying evidence based practices in instruction.

\section{THE ROLE OF PARENTS AND TEACHERS IN THE DEVELOPMENT OF MOTIVATION OF DEAF AND HARD OF HEARING STUDENTS TO LEARN AND ACADEMIC ACHIEVEMENT}

A child's interest and motivation in science will influence his confidence in activities and observational learning that a child (Lang, 2006; see Naidoo, 2009).

Some authors point out that that DHH students have even larger interest for studying, practicing curriculum, adopting new contents but that there is also indifference and unconcern. Deaf persons do not have enough motivation and developed interests (Levine, 1981; see Radoman, 2003). "Factors which create challenges for the learners and the educators were categorized as intrinsic factors (which included literacy, sign language, interest \& motivation and assimilation) and extrinsic factors (the science curriculum, parental involvement and resources"(Naidoo, 2009, p. 103).

The motivation of deaf and hard of hearing students may be affected by poor auditory perception, which leads to difficulties in understanding and mastering certain classroom contents, which in turns diminishes the interest in a certain area and the student fails to make an effort to master the material. If a student's attention has been attracted to a particular material, by means of easy to understand and appropriately introduced content, he/she will understand the purpose of learning, which will in turn arouse his/her interest and thereby his/her persistence in performing activities related to the task. The task of parents and teachers is to strengthen and support the competence and autonomy of deaf and hard of hearing students, which will serve to also strengthen their self-esteem and self-efficiency, as well as their motivation to learn and to attain academic achievement. 
Many participants in Reiff et al.'s (1995; see Jacobs, 2010) study reported that anger originating from incidents in childhood, particularly anger toward the school system, was a catalyst for what would later become successful professional and social outcomes. Other participants maintained their Desire into adulthood through rewards gained from particular endeavors, encouragement from significant others (e.g., family and teachers), or understanding that basic academic survival required sustained determination. Many participants also appeared determined to prove the stereotypes of their disability wrong (e.g., low expectations imposed by others) and that these external influences would not decide their fate.

Parental and teacher expectations for deaf students and perhaps students 'expectations for themselves play an important role in academic success. Although there has been little attention given to achievement motivation in deaf children, Stinson (1974, 1978) found that hearing mothers of deaf children did not have as high expectations for their children's achievement motivation as hearing mothers of hearing children (Marschark, Convertino \& LaRock, 2006). The role of the family's value system in generating successful psychosocial outcomes has appeared in studies with students who were deaf and their families (e.g., Luckner \& Muir, 2001; Toscano et al., 2002; see Jacobs, 2010). Elements of these value systems included goal setting, constant motivation to achieve academically, acceptance of deafness, and not using deafness as an excuse for poor performance. Toscano, McKee, and Lepoutre (2002; see Marschark, Convertino, \& LaRock, 2006) found that deaf college students who demonstrated high academic literacy skills tended to have parents who were very involved in their early educations, effective family communication (regardless of mode), early and intensive exposure to reading and writing, and high expectations on the part of their parents. „Parental support, appropriate educational style and parent involvement, degree of support and control are positive factors in the development of self-esteem, social skills development and competence, motivation and school achievement" (Povlakić Hadžiefendić, Mahmutović, \& Hasanbegović, 2019, p. 83). „Although parental involvement in their deaf child's school-based education program can positively contribute to academic performance, parental communication skill is a more significant predictor for positive language and academic development" (Calderon, 2000, p. 140). Many participants in Reiff et al.'s (1995; see Jacobs, 2010) study emphasized the importance of emotional support and social connectedness that continued from childhood into adulthood. Participants reported that their parents persevered through external challenges, such as educators' discriminatory behaviors and low expectations.Parents helped instill a value system consisting of proactive lifestyle practices that led to proactive professional and social outcomes for their children.

According to McIntosh et al. (1994: 481; see Naidoo, 2009), instructional strategies are a key aspect of the role of the teacher. The teacher's interpretation of his or her role, what is taught, how it is taught, use of resources, attitudes and belief's determines how the learners feel about themselves and what they are learning.

Teachers should also bear in mind at all times that deaf and hard of hearing students are capable of learning and they should expect more from them. By fulfilling their tasks, teachers work to ensure that these students fully accept themselves, and they encourage and motivate them.

Skilled teachers of the deaf are able to motivate DHH students or utilize methods adapted to their strengths and needs such that those students can learn just as much as their hearing peers. Relatively little is known about the relation between teaching methods and academic outcomes for DHH students, however, even if some best practices have been identified (Spencer \& Marschark, 2010; see Richardson et al., 2010). „If we are to increase academic performance among children who are deaf or hard of hearing, we must renew our attention to effective instructional practices where measurement of student growth informs instruction and the decision-making process" (Rose, 2007, p. 7). 
Authors have argued that while much instructional classroom time with students who are deaf has been focused on academic subjects and the improvement of languageand speech skills, the curriculum generally does not cover the development of proactive psychosocial skills (Bowe, 2003; Calderón \& Greenberg, 2000; see Jacobs, 2010). „The many studies indicate that we need to re-examine our assumptions, conclusions, and approaches - in both research and education - if we really want to understand and optimize educational opportunities for individuals who are deaf or hard-of-hearing. The purpose of conducting assessment research and educational research, is to understand how our methods work, to ensure that they are valid and reliable, and to improve them. If we do not really understand the individuals with whom we are working it is impossible to provide fair and appropriate evaluations of what they know or develop teaching strategies to help them learn more“" (Marschark, 2001, p. 10). „Decades of research on educational and basic scientific questions relating to deaf children have yielded a wealth of knowledge about how they learn and develop as thinking, social, problem-solving individuals. However, we currently lack channels for communication from teachers to researchers about the priorities in education and from researchers to teachers about scientific progress that might be effectively utilized in the learning context. As a result, research often fails to address educational priorities, knowledge gained from relevant investigations is rarely translated into practice, and decision-making is often governed by administrative expedience rather than evidence" (Swanwick \& Marschark, 2010, p. 217).

\section{CONCLUSION}

Deaf and hard of hearing students approach classroom obligations and learning with varying interest. They set different goals when it comes to their academic achievement. There are various internal and external factors that correlate with academic achievement. According to the views of the author that are based on research results and practice, it appears that deaf and hard of hearing students usually have poorer academic achievement than their hearing peers, as well as a lower level of motivation to learn. The development of interest and motivation to learn among deaf and hard of hearing students is not paid sufficient and appropriate attention by both the students themselves and their environment (parents and teachers). If parents and teachers had high expectations of students and took into account all their personal characteristics and other external factors, and where parents and teachers were appropriately involved in the teaching process, deaf and hard of hearing students showed high levels of interest and motivation to learn and attained better academic achievement. In order to ensure high academic achievement of deaf and hard of hearing students, in addition to other factors, it is particularly important that there is a strong motivation to learn, appropriate involvement of parents, a high level of competence and engagement of teaches, and especially a connection between scientific research and practice, i.e. communication between teachers and researchers.

\section{REFERENCES}

Amrai, K., Motlagh, S. E., Zalani, H. A., \& Parhon, H. (2011). The relationship between academic motivation and academic achievement students. Procedia-Social and Behavioral Sciences, 15, 399-402. DOI: 10.1016/j. sbspro.2011.03.111

Brophy, J. (2004). Motivating students to learn [Second Edition]. London: Lawrence Erlbaum Associates, publishers. Retrieved from http:/www.erasmusgrobina.lv/images/ motivation/JereE.Brophy.Motivating-Students.pdf

Calderon, R. (2000). Parental involvement in deaf children's education programs as a predictor of child's language, early reading, and social-emotional development. Journal of deaf studies and deaf education, 5(2), 140-155. doi: 10.1093/deafed/5.2.140

Deci, E.L. \& Ryan, R.M. (2000). The" what" and" why" of goal pursuits: Human needs and the self-determination of behavior. Psychological inquiry, 11(4), 227-268. Retrieved from http://users.ugent.be/ wbeyers/ scripties2011/artikels/Deci\&Ryan_2000.pdf 
Dornan, D.A. (2010). Outcomes for Young Children with Hearing Loss in an Auditory-Verbal Therapy Program. Doctoral dissertation, University of Queensland, School of Health and Rehabilitation Sciences.

El-Zraigat, I.A. (2013). Assessing Special Needs of Students with Hearing Impairment in Jordan and Its Relation to Some Variables. International Education Studies, 6(2), 63-75. doi: 10.5539/ies.v6n2p63

Guthrie, J.T. \& Wigfield, A. (1999). How Motivation Fits Into a Science of Reading. Scientific Studies of Reading, 3 (3), 199-205. https://doi.org/10.1207/s1532799xssr0303_1

Hasanbegović, H., \& Sinanović, O. (2008). Procjena određenih psiholoških karakteristika kod gluhih osoba [Estimate of certain psychic characteristics at tested deaf people]. Acta Medica Saliniana, 37(2), 127-131.

Hasanbegović, H. (2008). Paradigmatično-pragmatična govorno-jezička metoda u edukaciji i rehabilitaciji slušno oštećene djece (orginalna metoda) [Paradigmaticpragmatic method in the development of cognitive abilities of hearing impaired children (original method)]. Didaktički putokazi, časopis za nastavnu teoriju i praksu, $45,50-55$.

Jacobs, P. (2010). Psychosocial potential maximisation: A framework of proactive psychosocial attributes and tactics used by individuals who are deaf. The Volta Revie, $110(1), 5-29$.

Marschark, M.(2001).Looking beyond the obvious: Assessing and Understanding Deaf Learners. Retrieved from https:// is-learn.esc11.net/stiggs/makingitmeaningful/story_ content/external_files/lookingbeyondtheobvious.pdf

Marschark, M., Convertino, C., \& LaRock, D. (2006). Optimizing academic performance of deaf students: Access, opportunities, and outcomes. In Moores, F. D. i Martin S. D. (Eds.). Deaf learners: New developments in curriculum and instruction (pp. 179-200). Washington, D.C. 20002: Gallaudet University Press

Marschark, M. i Spencer, P.E. (2009). Evidence of Best Practice Models and Outcomes in the Educationof Deaf and Hardof-Hearing Children: An International Review. Retrieved from http://www.ncse.ie/uploads/1/1_NCSE_Deaf.pdf

Moores, F. D, \& Martin, S. D. (2006). Overview: Curriculum and Instruction 3 in General Education and in Education of Deaf Learners. In Moores, F. D. i Martin S. D. (Eds.). Deaf Learners. Developments in Curriculum and Instruction (pp. 3-15). Washington, D.C. 20002: Gallaudet University Press

Naidoo, S. S. (2009). Science education for deaf learners: educator perspectives and perceptions. Doctoral dissertation, University of the Witwatersrand, Faculty of Humanities. Retrieved from http://146.141.12.21/ bitstrea m/handle/ $10539 / 5918 /$ M . ED\% 20 RESEARCH\%20REPORT.pdf? sequence=1
Ogundiran, O. \& Olaosun, A.O. (2013). Comparison of Academic Achievement between Students with Congenital and Acquired Deafness in a Nigerian College. Journal of Education and Practice, 4(23), 42-48. Retrieved from https://www.iiste.org/Journals/index.php/JEP/article/ view/8387/8688

Povlakić Hadžiefendić, M., Mahmutović, E.H., \& Hasanbegović, H. (2019). Perception of parental support by deaf and hardof-hearing students. Human Research in rehabilitation, 9(1):82-87.

Radoman, V. (2003). Psihologija jezika i jezičkih poremećaja [Psychology of language and language disorders]. Belgrade: Defektološki fakultet [Faculty of Special Education and Rehabilitation].

Rahmani, P. (2011). The relationship between self-esteem, achievement goals and academic achievement among the primary school students. Procedia-Social and Behavioral Sciences, 29, 803-808. doi:10.1016/j.sbspro.2011.11.308 Richardson, J. T., Marschark, M., Sarchet, T., \& Sapere, P. (2010). Deaf and hard-of-hearing students' experiences in mainstream and separate postsecondary education. Journal of deaf studies and deaf education, 15(4), 358-382. doi:10.1093/deafed/enq030

Rose, S. (2007). Monitoring Progress of Students Who Are Deaf or Hard of Hearing. Preuzeto sa https://files.eric. ed.gov/fulltext/ED502455.pdf

Swanwick, R. \& Marschark, M. (2010). Enhancing Education for Deaf Children: Research into Practice and Back Again Ruth. Deafness \& education international, 12 (4), 217-235. doi: 10.1179/1557069X10Y.0000000002 Vansteenkiste, M., Sierens, E., Soenens, B., Luyckx, K., \& Lens, W. (2009). Motivational profiles from a self-determination perspective: The quality of motivation matters. Journal of educational psychology, 101(3), 671-688. doi: 10.1037/ a0015083 